\title{
Hacia una concepción autónoma de la responsabilidad precontractual y su aplicabilidad en el ordenamiento jurídico peruano(*)(*)
}

\section{Towards an autonomous conception of pre-contractual liability and its applicability in the Peruvian legal system}

\author{
Rómulo Martín Morales Hervias ${ }^{(*+*)}$ \\ Pontificia Universidad Católica del Perú
}

\begin{abstract}
Resumen: El presente estudio propone reflexiones críticas a la tesis prevalente de la doctrina peruana que considera que la responsabilidad precontractual se subsume en la cláusula general de la responsabilidad extracontractual atípica. Además, se analiza un caso jurisprudencial judicial peruano para demostrar que es posible sostener en futuros casos jurisprudenciales la responsabilidad precontractual basada en la categoría de "una obligación sin prestación (conducta del deudor)" que emana de la buena fe objetiva.

Palabras claves: Obligaciones Pre-contractuales - Negociaciones contra la Buena Fe

Abstract: The present paper proposes critical reflections to the prevailing thesis of Peruvian doctrine that considers that pre-contractual liability is subsumed in the general clause of atypical extra-contractual liability. In addition, a Peruvian judgment is analyzed to demonstrate that it is possible to argue in future cases the existence of a pre-contractual obligation based on the category of "an obligation without benefit", which emanates from objective good faith.
\end{abstract}

Key words: Pre-contractual duties - Negotiations contrary to Good Faith

(*) Nota del Editor: El artículo fue recibido el 17 de noviembre de 2018 y aprobada su publicación el 21 de noviembre de 2018

${ }^{* *}$ Este ensayo fue parte de la ponencia desarrollada en setiembre de 2017 en el "Seminario Internacional de Derecho Privado. Planteamientos de problemas, perspectivas y retos para una solución", organizado por la Universidad Católica de Colombia.

${ }^{* * *}$ Abogado. Magíster por la Universidad di Roma "Tor Vergata". Diplomado en Derecho Romano; y en Derecho de los Consumidores y de la Responsabilidad Civil por la Universidad di Roma "La Sapienza". Doctor en Derecho por la Pontificia Universidad Católica del Perú. Profesor de Derecho Civil en la Facultad de Derecho y en la Escuela de Graduados de la Pontificia Universidad Católica del Perú (PUCP). Profesor de Derecho Civil en la Facultad de Derecho de la Universidad ESAN. Árbitro de las nóminas del Centro de Arbitraje de la Cámara de Comercio de Lima y de la Unidad de Arbitraje del Centro de Análisis y Solución de Conflictos de la PUCP. Contacto: romulo.morales@pucp.pe. 


\section{Introducción}

El presente estudio es uno que propone la aplicación de las disposiciones normativas de la responsabilidad por incumplimiento de obligaciones a los casos de la responsabilidad precontractual(1). Este tipo de responsabilidad es autónoma en el sentido que es una consecuencia por incumplir deberes precontractuales que emanan de un deber general de la buena fe objetiva a diferencia de otros deberes contractuales o deberes negociales.

La mayor parte de los contratos contemporáneos se desarrollan en un proceso genético donde no necesariamente existe la adquisición de información suficiente de las calidades de los bienes o de los servicios como en los contratos de consumo. Así, la responsabilidad precontractual de las empresas que venden bienes y prestan servicios es un problema de disconformidad entre el interés del consumidor sobre los bienes o los servicios; y el contrato celebrado. En los contratos de consumo no hay negociación. El empresario elabora unilateralmente las cláusulas. De ahí que la mayoría de la legislación de consumo de aparente protección al consumidor se le exija que lea y además comprenda el contenido de dichas cláusulas que él no las negoció en lugar de exigir al empresario que exista objetivamente la conformidad entre el interés del consumidor sobre el bien o el servicio; y el contrato.

Por otro lado, antes de la celebración de contratos, donde sí hay negociación, hay dos fases. La "fase negociadora (preparación del contenido del acuerdo) y la ulterior fase decisoria (emisión de las declaraciones de voluntad: la oferta y la aceptación (...)). Por lo tanto, integran la fase negociadora los actos preparatorios realizados sin la intención vinculante, desde los contactos iniciales de las partes negociadoras hasta la formación de la oferta contractual definitiva. Es el periodo de «trattative», "pourparlers», "Verhandlungen», conforme a la terminología italiana, francesa y alemana respectivamente. Obsérvese la circunstancia de autores brasileños se refieren a las «tratativas» y la «fase de las tratativas», en correspondencia aquél vocablo italiano" (Almeida Costa, 2006, 270-271). Así por ejemplo, "A desea adquirir un inmueble, y con esa intención, procede a las investigaciones sobre las particularidades del mismo indicadas por el vendedor, discute con él algunas adaptaciones, así como el precio y los términos de pago; $B$ pretende constituir una sociedad destinada a la fabricación de cierto producto, para que, más allá de los futuros socios, se hace necesario realizar ensayos, análisis, búsquedas, prospección de mercado, etc; $C$, empresario, quiere obtener la colaboración de $D$, un técnico especializado, no solo negocia las cláusulas contractuales, además lo invita a hacer una estancia en su fábrica; y le aplica pruebas y entrevistas. Piénsese, por ejemplo, en la celebración cuidadosa que reclaman los llamados contratos «llave en mano» («clé en main», «turnkey contract») de cuantiosa importancia, los negocios referidos a la adquisición de grandes lotes de acciones y los contratos de transferencia de tecnología, que, a menudo, asumen ámbito internacional" (Almeida Costa 2006, 268).

Estos ejemplos describen el proceso genético de las negociaciones. Las "partes negociadoras deben observar un comportamiento que no perjudique la buena marcha de las negociaciones" (Hörster 2005, 473). En efecto, las "partes en la negociación revelan sus necesidades y conveniencias, sus apetencias negociales y los objetivos que las mueven, incurren en gastos y asumen riesgos. Las partes negociadoras se colocan muchas veces en posiciones de fragilidad, asumen riesgos y se exponen a peligros. Entre las partes negociadoras se establecen relaciones de confianza que son más o menos intensas. Hay siempre un mínimo de confianza sin la cual ninguna negociación es posible" (Pais de Vasconcelos 2005, 328).

Sin duda este estudio es la continuación de nuestra defensa a la categoría(2) de los deberes de protección (Morales Hervias 2013, 285-311) por cuanto la responsabilidad precontractual desde nuestra perspectiva es un caso paradigmático de la categoría de obligaciones sin prestación. Ello lo corrobora una doctrina italiana: "Toda la teoría de la obligación sin prestación se basa en la categoría de las obligaciones de protección generados por la buena fe" (Castronovo 2009, 702). Desarrollaremos un específico discurso sobre por qué la responsabilidad precontractual no debe ser regulada por el instituto de la responsabilidad extracontractual (según la denominación del Código Civil peruano de 1984). Al contrario, aseveramos la responsabilidad precontractual tiene una proximidad a la lógica de la responsabilidad por

(1) "La expresión más rigurosa será de la responsabilidad prenegocial, dado que el problema trasciende el puro dominio de los contratos. Se concibe, designadamente, en relación a los negocios jurídicos unilaterales" (Almeida Costa 2006, 270). En el presente estudio utilizaremos la expresión "responsabilidad precontractual" porque la mayoría de los casos discutidos en la doctrina y en la jurisprudencia comparadas se refieren a los daños producidos en las etapas previas a la formación de los contratos.

(2) Las categorías son "criterios de clasificación, formas, determinaciones generales que permiten pensar las cosas y por ello entenderlas. Todo hecho cultural exige ser expresado en estructuras categoriales" (Lipari, Nicolò 2013. Le categorie del diritto civile. Milán: Giuffrè Editore, 11). 
inejecución de obligaciones (según la terminología del Código Civil peruano de 1984). De ahí que no compartimos la posición de una doctrina italiana que sostiene lo siguiente: "no es posible hipotizar un tercer género de responsabilidad por fuera de la alternativa entre responsabilidad contractual y responsabilidad aquiliana, esto es, entre la violación de una relación obligatoria particular y la violación de una de las obligaciones genéricas que informan la vida de relación" (Bianca 2007, 178).

Nuestro disenso se basa en que la responsabilidad precontractual es un efecto de una obligación sin prestación a diferencia de una obligación con prestación. Nuestro punto de vista no solo obedece a una cuestión dogmática o de la ciencia del derecho sino también a una cuestión eminentemente práctica. ¿Cómo se enseñan en las facultades de Derecho la aplicación de la responsabilidad precontractual? ¿Cómo los abogados se enfrentan a casos concretos de responsabilidad precontractual cuando sus clientes son damnificados en la etapa de las tratativas? ¿Qué criterios aplicarán los jueces y los árbitros ante casos concretos de responsabilidad precontractual? En el Perú no hay jurisprudencia abundante (hay una judicial que la comentaremos aquí) como en nuestros formantes ${ }^{(3)}$ jurídicos italiano y portugués, a los cuales nos referiremos en el presente estudio, a pesar de las pocas disposiciones normativas. La diferencia está en el alto desarrollo de la cultura jurídica en esos países y consecuentemente los involucrados adquieren un mejor conocimiento de la responsabilidad precontractual. $\mathrm{Si}$ añadimos que algunos países sudamericanos les siguen los pasos como Brasil y Colombia. El Perú no puede estar a la espalda de estas construcciones teóricas de indudable alcance práctico para salvaguardar intereses precontractuales dignos de tutela. Así que no hay que temer preguntarse por la naturaleza jurídica de la responsabilidad precontractual. Una doctrina brasileña lo aclara:

"Se trata de un intento de categorizar institutos de modo de permitir un análogo tratamiento teórico y práctico de figuras jurídicas que se asemejan. No se trata de una preocupación de orden exclusivamente doctrinario, porque la delimitación de la naturaleza jurídica produce importantes contornos materiales ligados a la identificación de un régimen jurídico apto para tutelar un determinado instituto. El estudio de la responsabilidad precontractual también debe impregnar por el análisis de su naturaleza jurídica. Esa categorización se hace importante para la definición del cuerpo de normas apto de ofrecer la adecuada salvaguarda a las situaciones de daños en fase precontractual" (Pereira 2017, 129-130).

En resumen, la responsabilidad precontractual tiene una naturaleza jurídica y es imperativo conocerla en base a argumentos claros y pertinentes.

\section{Crítica a alguna doctrina italiana que defiende la tesis que responsabilidad precontractual se subsume en la responsabilidad extracontractual atípica}

Citaremos y analizaremos críticamente a alguna doctrina italiana traducida al castellano que a su vez ha sido considerada por la doctrina peruana prevalente. Una doctrina se adhiere a:

"la posición que vincula la responsabilidad ex artículo $1337^{(4)}$ al género extracontractual" (...). La obligación y la responsabilidad contractual protegen ese específico interés del acreedor que es el interés a la prestación (artículo 1174(5)). Diversos son los intereses de la vida de relación puestos en riesgo en el contacto social: de la seguridad en la circulación automovilística a la lealtad en la competencia económica a la corrección y seriedad en las tratativas contractuales. Para su protección se imponen a los operadores deberes de conducta que pueden ser no genéricos -sino calibrados sobre las especificidades de los intereses, de las actividades, de los riesgos en juego-, pero no por esto generan obligaciones. Y su violación genera responsabilidad extracontractual" (Roppo 2009, 189).

En verdad estas afirmaciones son erróneas por cuanto la responsabilidad extracontractual no es una consecuencia de violación de deberes específicos que emanan del deber de buena fe.

Otra doctrina ha señalado lo siguiente:

"la cuestión no debe centrarse en continuar interrogándose sobre el artículo 1337, sino en interpretarse el artículo $2043^{(6)}$. Si el artículo 1337 no existiese, ¿la deslealtad no vendría reprimida por el ex artículo 2043? ¿Y cuál sería entonces la labor del artículo 1337? ¿Quizás éste pretende

(3) "Los principales formantes que encontramos en los sistemas modernos son la ley, la jurisprudencia, y la doctrina. Es decir, el conjunto de disposiciones emanadas por el legislativo, el conjunto de las decisiones de los jueces y el conjunto de las opiniones expresadas por los juristas. El rol de estos factores, o formantes, del derecho cambia de sistema a sistema y de época a época": Mattei y Monateri, $1997,14$.

(4) Artículo 1337 del Código Civil italiano de 1942. Tratativas y responsabilidad precontractual.- En el desenvolvimiento de las tratativas y en la formación del contrato, las partes deben comportarse según la buena fe.

(5) Artículo 1174 del Código Civil italiano de 1942. Carácter patrimonial de la prestación.- La prestación que constituye el objeto de la obligación debe ser susceptible de valoración económica y debe corresponder a un interés, aun cuando no sea patrimonial, del acreedor.

(6) Artículo 2043 del Código Civil italiano de 1942. Resarcimiento por hecho ilícito.- Todo hecho doloso o culposo que causa a otro un daño injusto obliga a aquel que ha cometido el hecho a resarcir el daño. 
crear una obligación, con el objetivo de dar vida a una duplicidad del artículo 2043, y ubicar un nuevo caso de cúmulo de responsabilidad contractual y delictual? ¿O en cambio el artículo 1337 interpreta el artículo 2043, para volver incontestable el argumento que el daño infringido con la deslealtad precontractual es «injusto»? A nuestro juicio, la respuesta a dar en la primera y la segunda interrogantes es positiva. La culpa prevista en el artículo 1337 es por tanto extracontractual. Así se orienta la jurisprudencia y sobre esta misma línea también la doctrina prevalente; a ella se contrapone, por otro lado, voces autorizadas, orientadas en sentido opuesto" (Sacco y De Nova 2004, 260-261).

En réplica a esta posición se ha señalado que no se puede compartir que el artículo 1337 es una responsabilidad extracontractual por cuando toma en cuenta las:

"ideas de los escritores sobre el viejo código cuando faltaba una norma análoga al artículo 1337, olvidando que el problema de la naturaleza de la culpa in contrahendo se coloca en otros términos diversos (...) el artículo 1337 constituye una extensión de la buena fe contractual a la fase de las tratativas (...) y por lo tanto parece coherente para una correcta reconstrucción de nuestro sistema atribuir idéntica naturaleza a la responsabilidad por violación del deber de buena fe sea que se vincule a la relación contractual sea que se fundamente sobre la relación prenegocial: si en el primer caso la responsabilidad tiene carácter contractual y es regulada por el principio del artículo $1218^{(7)}$, otra cosa debe decirse para el segundo. A ello se añade que los deberes expresos por la buena fe del artículo 1337 tienden también a la promoción y a la satisfacción de otra expectativa y por eso también tienen un propósito positivo, con ello se diferencia de aquellos del artículo 2043 que están dirigidos exclusivamente a proteger, no a realizar otro interés y por lo tanto tienen solo un propósito negativo" (Benatti 1991, 8).

Esta réplica es muy clara y contundente. El deber de la buena fe de la responsabilidad precontractual se concreta en conductas que generan confianza en la contraparte que está actuando conforme a los deberes precontractuales. En la responsabilidad extracontractual no existen deberes previamente establecidos.

Otra doctrina italiana sostiene la posición de la responsabilidad precontractual como una hipótesis de la responsabilidad extracontractual:

"En las negociaciones las partes deben comportarse, ciertamente, de acuerdo con la buena fe, pero deben también comportarse con diligencia. La responsabilidad precontractual se reconoce, en efecto, en las hipótesis de comportamiento culposo del sujeto que, por ej., lleva adelante las negociaciones sin verificar sus posibilidades concretas de comprometerse, o cuando celebra el contrato sin verificar las causas de invalidez que están bajo su control. Esto significa que la responsabilidad precontractual puede tener fundamento, no sólo en la no corrección, sino también en la culpa, según la regla general de la responsabilidad extracontractual (...) En conclusión, la responsabilidad precontractual indica la responsabilidad por lesión de la libertad negocial ajena, que se puede presentar por la concurrencia de un comportamiento doloso o culposo, o también, por la inobservancia del precepto de la buena fe" (Bianca 2007 176-177).

Esta misma doctrina refuerza su tesis con el argumento que los deberes genéricos se concretan en deberes específicos por los contactos sociales:

"La circunstancia de que la obligación de buena fe deba ser observada por los contratantes durante la «relación» precontractual, no quiere decir que se trate de una relación obligatoria entre sujetos determinados. Todos los deberes genéricos de la vida en relación se concretan en comportamientos debidos frente a las personas con las que se entra en contacto. Así, por ej., las reglas de tránsito automovilístico se traducen en determinados comportamientos que debe observar quien conduce un vehículo frente a los demás, sin que por eso se constituyan relaciones obligatorias. Contra la tesis contractual resulta importante señalar, además, que la obligación se pone a cargo de un sujeto determinado para satisfacer un interés individual específico (el interés del acreedor: artículo 1174, Código Civil), mientras la obligación genérica se pone a cargo de los coasociados para tutelar intereses de la vida de relación, susceptibles de ser afectados por los contactos sociales. Ahora, justamente, el interés que importa en la responsabilidad precontractual es un interés en la vida de relación, que es, precisamente, el interés a la libertad negocial. En general los coasociados deben actuar con la diligencia ${ }^{(8)}$ adecuada para no

(7) Artículo 1218 del Código Civil italiano de 1942.- Responsabilidad del deudor.- El deudor que no realiza exactamente la prestación debida está obligado al resarcimiento del daño a menos que pruebe que el incumplimiento o el retardo han sido determinados por imposibilidad de la prestación derivada de causa no imputable a él.

(8) Esta referencia a la "diligencia" coincide con otra doctrina italiana la cual señala que el deber de diligencia es el deber de la responsabilidad extracontractual "necesariamente destinado a ser individualizado y concretizado, es decir, está destinado a aplicarse en modo singular 
lesionar tal interés y, además, deben observar el precepto de la buena fe (...) La lesión de la libertad negocial ajena se encuadra, por lo tanto, de manera apropiada, en el ámbito de la responsabilidad extracontractual” (Bianca 2007, 178).

Finalmente, esta doctrina sostiene que "responsabilidad precontractual denota la responsabilidad por la lesión a la libertad negocial. La responsabilidad precontractual no tutela el interés en el cumplimiento, sino el interés del sujeto en no ser envuelto en tratados inútiles, en no estipular contratos inválidos o ineficaces, y en no sufrir presiones o engaños en razón de los actos negociales" (Bianca 2007, 175-176). Disentimos de esta tesis porque si el valor a proteger es la libertad negocial se contradice con el valor que verdaderamente se busca proteger en las tratativas. Ese valor no puede ser otro que la confianza que la contraparte negociadora actúe conforme a los deberes específicos precontractuales como los deberes de información, de claridad, de secreto, de protección y tantos otros que surgen no solo de la ley sino también de la práctica contractual. Dichos deberes emanan del deber de la buena fe. Ahora bien, la tesis del contacto social aplicable a la responsabilidad extracontractual no puede explicar otra categoría denominada contacto social calificado la cual justifica el nacimiento de obligaciones sin prestación que emanan de la buena fe objetiva.

En todo caso para que las doctrinas citadas logren una aplicación coherente se tendría que aceptar la siguiente doctrina la cual se adhiere que la responsabilidad precontractual se somete al régimen de la responsabilidad extracontractual y por eso:

"Una vez establecida la objetiva oposición entre el comportamiento del agente y el deber de lealtad que se impone en el artículo 1337 Código Civil, la determinación de la responsabilidad precontractual no requiere la verificación de un comportamiento particular y objetivo de mala fe. Para que exista el elemento psicológico que se exige en el artículo 2043 cód. civ., tampoco es necesaria la prueba de la intención de ocasionar perjuicio al otro contratante. En la infracción del deber de buena fe estamos, por lo tanto, ante la presencia de una culpa in re ipsa" (Monateri 2004, 533).

Al no requerirse un comportamiento particular y objetivo de mala fe en el fondo ya no sería necesario determinar qué deber específico precontractual se violó que emane del deber de la buena fe. Al contrario, para imputar responsabilidad precontractual debe obligatoriamente establecerse qué deberes precontractuales fueron vulnerados. Obviar dicho análisis equivaldría a imputar responsabilidad precontractual a una conducta de lesión a un deber de diligencia ajeno al de la buena fe. Justamente aquí yace la contradicción de la doctrina italiana citada. Se dice que responsabilidad precontractual es absorbida por la responsabilidad extracontractual en los casos de la denominada responsabilidad por contacto donde "de la buena fe/lealtad (correttezza) puede establecerse una relación obligatoria solo en el mismo sentido y con el mismo valor en que y con que se puede establecer la culpa/diligencia" (Barcellona 2011, 90). Consideramos que el deber extracontractual de diligencia no puede subsumir al deber de la buena fe como si el primero fuera un deber general y el segundo un deber específico. Cada deber tiene su propio contenido y aplicación. De ahí que son incompatibles. Y cabría preguntarse si la diligencia es un deber jurídico o simplemente una cuasi categoría sin valor jurídico para aplicarlo a la responsabilidad extracontractual atípica.

En efecto, la "buena fe objetiva es una cláusula general(9) cuyo contenido, no completa ni analíticamente determinado ex ante por el legislador, se especifica en el desarrollo de la fase de las tratativas y de la formación del contrato en una serie de obligaciones de comportamientos (obblighi comportamentali) de lealtad (corretteza) y además (...) de diligencia recíprocos y a cargo de ambas partes, derivadas e impuestas por las circunstancias concretas de la relación. Ellas pueden sintéticamente resumirse en obligaciones (obblighi) de claridad, de información o aviso y de colaboración, de secreto y de "protección» de otra esfera jurídica" (Turco 2011, 410). Una doctrina brasileña de reconocido nivel reconoce que la buena fe cumple una función optimizadora del comportamiento contractual "por imposición de deberes de cooperación y de protección de los recíprocos intereses, deberes instrumentales de conducta, por lo que buscan el exacto desarrollo de la relación obligacional, la satisfacción de los intereses globales involucrados, auxiliando en la realización positiva del fin contractual y en la protección a la persona y a los bienes de la

y determinado (...) el deber extracontractual se aplica exclusivamente a "cualquiera" absolutamente singular que se encuentra en condiciones de proximidad, en el riesgo de interferencia con otro "cualquiera" igualmente determinado, que puede resultar dañado por esta proximidad o por la interferencia alegada": Barcellona, 2011, 93-95.

(9) "Para obviar el inconveniente y de garantizar al mismo tiempo una más rápida adecuación de las propias normas a las cambiantes exigencias de la realidad social, el ordenamiento jurídico prefiere a veces recurrir a normas estructuradas en términos de cláusulas generales: ellas están formuladas de modo ya no analítico, sino más amplio y elástico y como tales idóneos para mejor recomprender su previsión abstracta el mayor número posible de casos concretos desarrollados en la práctica, funcionando como verdaderos y propios «órganos respiratorios» o «válvulas de escape» del mismo ordenamiento" (Turco 2011, 23). 
contraparte" (Martins-Costa 2002, 80). Una doctrina brasileña reciente ha expresado que "la buena fe objetiva se presenta como una cláusula general. De esta afirmación es posible extraer que, dentro de la concepción de sistema de nuestro ordenamiento jurídico, la buena fe se presenta como importante canon integrativo de normas. Por medio de la aplicación de las cláusulas generales como la buena fe objetiva, es posible una constante actualización del sistema jurídico, llevando su comprensión como un sistema abierto" (Pereira 2017, 105). Asimismo, una doctrina colombiana describe la "buena fe integradora" la cual "produce un enriquecimiento del contenido contractual, ya que a través de ella se dota un sentido más amplio a los deberes creados por el negocio jurídico y también se origina una serie de deberes especiales, que atienden particularmente a la naturaleza del contrato y a su finalidad. Así, el contenido del artículo $1258^{\left({ }^{10}\right)}$ del Código Civil, no sólo tiene la pretensión negativa de prohibir los actos abusivos y fraudulentos, sino además la virtualidad positiva de obligar a los extremos negociales al comportamiento leal y a la confianza mutua" (Monsalve Caballero 2014, 338-339).

En consecuencia, la buena fe integradora es la buena fe objetiva la cual se aplica perfectamente a las negociaciones. Es evidente que la cláusula normativa general de la responsabilidad extracontractual atípica no está en condiciones de lograr la especificidad que logra una cláusula general de buena fe objetiva.

\section{La doctrina peruana adherente a la tesis de la responsabilidad precontractual subsumida en la cláusula general de la responsabilidad extracontractual atípica}

Nuestra opinión es contraria a la tendencia prevalente de la doctrina nacional que reconoce que la responsabilidad precontractual se subsume en la responsabilidad extracontractual. Así, por ejemplo: "El deber de actuar de buena fe en la etapa de las tratativas no es otra cosa que una manifestación específica del deber genérico de no causar daño, pues, siendo exigible a todos los que intenten celebrar un contrato (o que efectivamente consigan su objetivo), tiene como finalidad mantener indemne la esfera de los protagonistas, de modo que éstos no sufran daños injustos". Esta posición no toma en cuenta los presupuestos específicos de la responsabilidad precontractual y además deja sin contenido a la categoría de la buena fe en su sentido objetivo.

Hay un dato normativo seguro, pero no es determinante para defender nuestra tesis de la responsabilidad precontractual ajena a la responsabilidad extracontractual. El artículo 1362 del Código Civil peruano de 1984 (que regula la hipótesis de la responsabilidad precontractual) está ubicada en la Sección
Primera (Contratos en General) del Libro VII (Fuentes de las Obligaciones) a diferencia de la Sección Sexta (Responsabilidad extracontractual). Esta distinción de las dos responsabilidades en opinión de una doctrina italiana "coincide precisamente con la distinción entre deberes relativos y derechos absolutos, o mejor -adoptando la terminología técnica propuesta por S. Romano, Frammenti di un dizionario giuridico, Milán, 1947, página 105- entre obligaciones (obblighi) y deberes en sentido estricto" (Mengoni 2011, 268). En doctrina nacional ya se esbozó esta defensa: "la responsabilidad derivada de la violación del deber de actuar según las reglas de la buena fe que impone a los tratantes, el artículo 1362 $2^{(11)}$ del Código Civil peruano de 1984, está regulada por las normas relativas a la inejecución de las obligaciones contempladas en el Título IX del Libro VI del Código Civil" (De La Puente y Lavalle 2007, 370-371). No obstante, esta aseveración no es suficiente.

La objeción más convincente es que subsumir la categoría de la responsabilidad precontractual a la responsabilidad extracontractual "genera una deformación del significado y de la función que la ley atribuye a la buena fe en este campo. La buena fe no podría ser entendida en sentido objetivo (como, por el contrario pretenden los defensores de la concepción aquí opuesta, sin darse cuenta de la contradicción en que incurren), en el sentido de ser una norma objetiva de conducta asumida como criterio de especificación de una serie de obligaciones (obblighi) recíprocas, impuestas a las partes en las tratativas independientemente del resultado de la celebración de un contrato válido" (Mengoni 2011, 269-270).

Así las cosas, la responsabilidad extracontractual y la buena fe son incompatibles:

"La responsabilidad extracontractual está esencialmente relacionada a la violación de los deberes absolutos que surgen fuera de una relación específica entre sujetos determinados, y es cierto que la determinación del contenido de los correspondientes los derechos absolutos es extraña una valoración de la misma

(10) Artículo 1258 del Código Civil español de 1889.- Los contratos se perfeccionan por el mero consentimiento, y desde entonces obligan, no sólo al cumplimiento de lo expresamente pactado, sino también a todas las consecuencias que, según su naturaleza, sean conformes a la buena fe, al uso y a la ley.

(11) Artículo 1362 del Código Civil peruano de 1984.- Los contratos deben negociarse, celebrarse y ejecutarse según las reglas de la buena fe y común intención de las partes. 
manera de la buena fe. En la hipótesis del artículo 1337, si la buena fe es entendida en sentido subjetivo, como calificación subjetiva de la violación de los deberes de conducta que cada parte tiene frente a la otra en cuanto tal, pero en cuanto tercero titular de derechos absolutos que, por la relación creada por las tratativas, están de hecho sujetos a una concreta posibilidad de lesión por obra de la contraparte. De tal modo, el artículo 1337 no sería una norma constitutiva de obligaciones (obblighi) entre los sujetos de las tratativas, pero tendría una sola función de fijar un elemento subjetivo necesario para el resarcimiento del daño derivado de la violación de deberes ya existentes independientemente del artículo 1337. Precisamente, el significado de la disposición sería el siguiente: el daño injusto, a una parte de las tratativas de un comportamiento de la otra parte causalmente conectado a la específica relación generada para la formación de un contrato, es resarcible solo en cuanto el daño se comete de mala fe. El artículo 1337 regularía una figura especial del hecho ilícito, donde la misma responsabilidad del autor no sería establecida por la regla de la culpa-diligencia sancionado en el artículo 2043, sino por la mala fe (...) De la letra del artículo 1337, la construcción de la responsabilidad precontractual como responsabilidad extracontractual lleva inevitablemente a eliminar el concepto de culpa in contrahendo" (Mengoni 2011, 269).

Nótese que las reflexiones de esta doctrina italiana lúcida y vigente es aplicable perfectamente al ordenamiento jurídico peruano al igual como sucede con algunas doctrinas portuguesas y brasileñas por cuanto utilizan la categoría de la buena fe precontractual alejada de la responsabilidad extracontractual atípica.

Un ejemplo concreto de cómo la buena fe se reduce a su más mínima expresión a la responsabilidad extracontractual atípica es la concepción de la responsabilidad precontractual como "responsabilidad fundamentada sobre el elemento subjetivo de la mala fe la cual encuentra un obstáculo definitivo en el artículo 1398 ${ }^{(12)}$ (equivalente al artículo 161 del Código Civil peruano de 1984), que sí se aplica el principio del artículo 1337 (equivalente al artículo 1362 del Código Civil peruano de 1984) al «falsus procurator» cuando la responsabilidad se fundamenta sobre el hecho objetivo de la falta de comunicación del defecto del apoderamiento al otro contratante" (Mengoni 2011, 270).

Por el contrario, "en la concepción que vincula la responsabilidad precontractual a una particular relación obligatoria constituida (ex lege) entre las partes de las tratativas, la relevancia de la culpa imputable al contratante engañado se explica fácilmente en relación a la fattispecie ${ }^{(13)}$ de tal relación obligatoria: según la cual el elemento de primer orden es una situación de confianza objetivamente valorable, que justifica la confianza de una parte en la regularidad del comportamiento de la otra" (Mengoni 2011, 271). Estas aseveraciones también son aplicables al artículo $161^{(14)}$ del Código Civil peruano de 1984 a diferencia de alguna doctrina nacional que la relaciona a la responsabilidad extracontractual mediante el artículo 1969(15) del Código Civil peruano de 1984. Así, se ha dicho lo siguiente: "Dada la naturaleza de la representación, frente al representado (o falso representado) es de carácter extra-contractual. En mi opinión, frente al tercero, es la misma naturaleza" (Espinoza 2012, 138). Y esta doctrina añade: "Independientemente del "contacto» del representante que se excede, abusa o del falso representante, lo que ha infingido es el deber genérico de no dañar" (Espinoza 2012, 139).

Otra doctrina nacional ha aseverado en el mismo sentido de considerar que el régimen extracontractual (artículo 1969 del Código Civil peruano de 1984) es aplicable al artículo 161 del Código Civil peruano de 1984 con argumentos diferentes pero reconoce dos formantes donde sí se aplica la buena fe precontractual: Para el formante italiano: "Sin negar que sea digno del mayor auspicio el empleo del artículo 1362 a la manera de los magistrados italianos, que aprovechan de forma ejemplar su equivalente artículo 1337, el convencimiento ahora reafirmado tiene un sólido punto de apoyo en aquellos discursos doctrinales sobre el resarcimiento de los daños in contrahendo que prescinden, convenientemente, de la buena fe" (León 2017, 736). Para el formante portugués: "Sobre la base de una norma explícita del Código Civil de 1966, en la que se establece que 'aquel que

(12) Artículo 1398 del Código Civil italiano de 1942. Representación sin poder.- El que hubiera contratado como representante sin tener poderes para hacerlo o excediendo los límites de las facultades a él conferidas, es responsable del daño que el tercero contratante ha sufrido por haber confiado, sin su culpa, en la validez del contrato.

(13) Fattispecie comporta "imagen o figura del hecho previsto por la norma jurídica": IRTI, Natalino. Un diritto incalcolabile. Turín: G. Giappichelli Editore. 2016. página 172: "De aquí -como ha enseñado Emilio Betti- la expresión técnica «fattispecie», facti species, es imagen o figura del hecho, diseñada por la norma en coherencia con el contenido de la regulación".

(14) Artículo 161 del Código Civil peruano de 1984.- El acto jurídico celebrado por el representante excediendo los límites de las facultades que se le hubiere conferido, o violándolas, es ineficaz con relación al representado, sin perjuicio de las responsabilidades que resulten frente a éste y a terceros.

También es ineficaz ante el supuesto representado el acto jurídico celebrado por persona que no tiene la representación que se atribuye.

(15) Artículo 1969 del Código Civil peruano de 1984.- Aquel que por dolo o culpa causa un daño a otro está obligado a indemnizarlo. El descargo por falta de dolo o culpa corresponde a su autor. 
negocia con otro para la celebración de un contrato debe actuar, tanto en las tratativas cuanto en la formación de éste, según las reglas de la buena fe, bajo sanción de responder por los daños causados culposamente a la otra parte' (artículo 227, párrafo 10.), el modelo alemán, entroncado en la cláusula normativa general de buena fe, las relaciones obligativas nacidas del contacto negocial, los deberes de protección y la protección resarcitoria de la confianza, se ha afirmado sin inconvenientes, con el apoyo de una doctrina realmente admirable" (León 2017, 736).

Estimamos que la "propuesta de adoptar el modelo francés de protección frente a los daños precontractuales, construido sobre la base de la cláusula normativa general de la responsabilidad extracontractual" (León 2017, 735) es incompatible con un ordenamiento jurídico que ha regulado expresamente la buena fe precontractual (artículo 1362 del Código Civil peruano de 1984) al igual que el artículo 1337 del Código Civil italiano de 1942. Ambas disposiciones normativas tienen un defecto: La norma jurídica "se reduce a la proposición hipotética 'Si A, entonces B': donde A indica una clase de eventos típicos, y $B$ la consecuencia vinculada al acontecimiento de ella" (Irti 2016, 138). El defecto consiste en la laguna de no haber regulado la consecuencia $B$ que sí la contempló el Código Civil de Portugal de 1966 (primer párrafo del artículo 227). Pero ello no es óbice para un sector de la doctrina italiana apliquen el régimen de la responsabilidad por incumplimiento de obligaciones a la responsabilidad precontractual mediante la integración jurídica del principio general de quien viola un deber específico que emane de la buena fe en sentido objetivo, está obligado a resarcir los daños. Para ello será determinante qué tipo de deber se incumplió a diferencia del "oscuro y nunca aclarado concepto del alterum non laedere" (Thiene 2009, 318). En el Perú tampoco debería ser un obstáculo realizar la misma integración jurídica. Nada lo impide. Este razonamiento no cae en la tentación de preferir un régimen por motivos sentimentales por un formante admirable sino se fundamenta en seguir un razonamiento coherente de cómo los deberes precontractuales son diversos y que dichas pluralidades de deberes no pueden emanar de la cláusula general de la responsabilidad extracontractual atípica. De ahí que las palabras de Mengoni siguen estando vigentes no solo para Italia y Portugal sino también para el Perú.

La réplica a esta tendencia de la doctrina nacional es otorgar el verdadero significado de la buena fe como "el significado objetivo de norma de conducta, deducida de la lealtad (correttezza) del bonus vir y deducida como criterio de determinación del contenido del contrato y de los efectos obligatorios que se derivan. Con la disposición del artículo 1337 (equivalente al artículo 1362 del Código Civil peruano de 1984) el nuevo legislador ha extendido el imperativo de la buena fe a la fase de las tratativas y a la de formación del contrato, y ello importa que las obligaciones recíprocas de lealtad (correttezza), de las cuales se refieren en el artículo $1175^{(16)}$, surgen ya en esta fase en función del específico interés de protección de cualquier parte en contraposición de la otra en cuanto tal, y por ello, mediante la relación instaurada de las tratativas, es considerada por una específica posibilidad (que de lo contrario no podría) de injerencias dañosas en la esfera jurídica de la contraparte. Cuando una norma jurídica regula el desenvolvimiento de una relación social al imperativo de la buena fe, aquello es un indicio seguro que esta relación social se ha transformado, en el plano jurídico, en una relación obligatoria, cuyo contenido se trata precisamente de especificar de la misma manera una valoración de buena fe. En realidad, el principio de la buena fe (en sentido objetivo) se ha desarrollado históricamente y se ha conservado como una directriz peculiar de las relaciones obligatorias, y por eso solo es concebible en el ámbito de aquellas relaciones. Por el contrario, la buena fe en sentido objetivo se resuelve en el concepto (objetivo) de incumplimiento, tanto que sobre esta situación, en el lenguaje romano la expresión «fidem praestare» designa el cumplimiento de una obligación (cfe. Krüger, en Zt-schr. Sav. St., II (1890), página 183, 184 y siguientes)" (Mengoni 2011, 272).

Hay un dato de derecho romano importante que responde a una objeción comparatista de que la contractualización alemana de la responsabilidad precontractual es inaplicable en el Perú:

"La responsabilidad de tipo extracontractual en Alemania, al igual que en Roma bajo el imperio de la actio legis Aquiliae, es de carácter típico (por lo que, a manera de ejemplo, en Alemania los así denominados daños meramente patrimoniales no pueden ser reparados a través de la responsabilidad extracontractual) y si a ello se le suma la circunstancia de la más que benigna carga probatoria que soporta el comitente o patrón frente a los daños ocasionados por sus dependientes (lo cual, en caso se optase por otorgar una tutela extracontractual, les facilitaría de modo irrazonable y en desmedro de las víctimas evadir cualquier responsabilidad por tales daños) frente a la responsabilidad del deudor que emplea terceros en la ejecución de la prestación a su cargo, en cuyos supuestos el deudor es responsable sin importar la diligencia que emplee" (Saavedra Velazco 2009, 555).

(16) Artículo 1175 del Código Civil italiano de 1942. Comportamiento con arreglo a la lealtad.- El deudor y el acreedor deben comportarse con arreglo a las reglas de la lealtad (corretteza). 
La respuesta está objeción ya la hizo una doctrina italiana:

"La aplicación del principio de la buena fe (objetiva) presupone por eso un específico vínculo obligatorio, presupone un deudor y un acreedor (arg. Ex artículo 1175 c.c.). Y se debería recordar que la moderna doctrina alemana, no disponiendo de una norma correspondiente a nuestro artículo 1337 (equivalente al nuestro 1362 del Código Civil peruano de 1984), aplicó la responsabilidad precontractual en los términos de una relación obligatoria individualizada mediante la extensión, a la fase de las tratativas y de la formación del contrato, del principio de la buena fe según el artículo $242^{(17)}$ (...) Se trata del mismo procedimiento que, en el derecho justinianeo, ha llevado la responsabilidad 'in contrahendo' sobre el plano de la responsabilidad contractual: la originaria actio doli extracontractual se sustituyó por la actio bonae fidei contractual precisamente a través de una extensión del iudicium bonae fidei a la fase de las tratativas y de la formación del contrato" (Mengoni 2011, 272-273).

Lo expresado líneas arriba es relevante en el caso del artículo 161 del Código Civil peruano de 1984. Si siguiéramos la lógica de que la cláusula general de la responsabilidad extracontractual (el artículo 1969 del Código Civil peruano de 1984) es aplicable a las hipótesis de la responsabilidad precontractual del artículo 161 del Código Civil peruano de 1984, en realidad debería aplicarse el artículo 1981(18) del Código Civil peruano de 1984. Una doctrina italiana expuso el mismo argumento:

"La teoría que aplica el artículo 1337 al artículo 2043 debe resolver la cuestión en realidad al artículo 2049(19) (equivalente a nuestro 1981 del Código Civil peruano de 1984), y debe en consecuencia limitar la responsabilidad del representado al caso en que el representante esté vinculado con él por una relación de dependencia (es decir, laboral). Solo la concepción de la llamada culpa in contrahendo como responsabilidad contractual admite extender el concepto de representación a la actividad desarrollada por el representante durante el proceso de formación del contrato, y por consiguiente admite de imputar la responsabilidad del representado incluso en el caso el apoderamiento sea conferido en base a una relación de mandato" (Mengoni 2011, 282).

Otra doctrina italiana en su momento admitió que la "relación representante-tercero no adquiere, en tema del ilícito in contrahendo, aquella relevancia que la acompaña en materia de ilícito extracontractual" (Sacco, 1951, 88). ¿Y por qué esta doctrina dijo ello aunque sucesivamente cambió de opinión?: "No se olvide que quien sufre un daño extracontractual no ha elegido la persona del dañador, no ha hecho voluntaria confianza sobre su honestidad y solvencia, mientras quien entra en relaciones in contrahendo con otros acepta espontáneamente el riesgo de su falta de solvencia por los daños de los cuales es responsable" (Sacco 1951, 88). Dichas aseveraciones siguen vigentes a pesar que el autor de ellas ha modificado su opinión. En cambio en Alemania con el numeral 1 del artículo $831^{(20)}$ permite al dueño del negocio eximirse de responsabilidad extracontractual si demuestra que fue diligente según los usos del tráfico a pesar que su subordinado causó daño a terceros en el ejercicio de sus funciones. Como bien dice una doctrina portuguesa:

"por el Derecho alemán, la responsabilidad del comitente, indicada en el artículo 831 del BGB, es débil: permite, al mismo comitente, eximirse de la responsabilidad por las reglas de la culpa in eligendo, esto es que la elección del comisionista debió realizar todo el cuidado requerido. Admitir tal esquema en el campo de las personas colectivas equivaldría a una potencial desresponsabilización (desresponsabilização) a larga escala" (Menezes Cordeiro 2010, 621).

Esta problemática alemana se solucionó contractualizando la responsabilidad del dueño del negocio mediante los deberes de protección. A diferencia del formante italiano, aplicable al peruano, donde el artículo 2049 -equivalente al artículo 1981 del Código Civil peruano de 1984- "esboza una previsión normativa de responsabilidad objetiva, que prescinde de la culpa y no permite al proponente de suministrar prueba liberatoria" (Breccia, Bruscuglia, Busnelli,

(17) Artículo 242 del Código Civil alemán de 1896.- El deudor está obligado a ejecutar la prestación como lo exige la buena fe y atendiendo a los usos del tráfico jurídico.

(18) Artículo 1981 del Código Civil peruano de 1984.- Aquél que tenga a otro bajo sus órdenes responde por el daño causado por éste último, si ese daño se realizó en el ejercicio del cargo o en cumplimiento del servicio respectivo. El autor directo y el autor indirecto están sujetos a responsabilidad solidaria.

(19) Artículo 2049 del Código Civil italiano de 1942.- Responsabilidad de los patrones y comitentes.- Los patrones y comitentes son responsables de los daños causados por el hecho ilícito de sus domésticos y encargados en el ejercicio de las actividades han sido delegadas a estos.

(20) Artículo 831 del Código Civil de 1896.-

1. Quien encarga a otro una actividad está obligado al resarcimiento del daño que el otro causa ilícitamente a un tercero en la ejecución de la actividad. La obligación de resarcimiento no surge si el dueño del negocio, en la elección de la persona encargada y en la contratación o en la dirección, ha observado la diligencia exigible en el tráfico jurídico, o si el daño incluso se hubiera producido igualmente con la observancia de dicha diligencia, en la medida en él debe adquirir dispositivos y herramientas o dirigir la ejecución de la operación. 
Giardina, Giusti, Loi, Navarretta, Paladini, Poletti y Zana 2010, 657). La problemática alemana tiene una solución distinta en Italia y en Perú. Y si deja de lado la culpa, ¿cómo queda la cláusula general de la responsabilidad extracontractual (el artículo 1969 del Código Civil peruano de 1984)? La respuesta es obvia. Dicha disposición normativa no sería aplicable si seguimos creyendo que la problemática alemana posibilitó la contractualización de la responsabilidad extracontractual. De ahí que una doctrina italiana ha dicho enfáticamente que interpretada:

"en términos de responsabilidad aquiliana, la regulación del artículo 1337 se reduciría a una banal repetición del deber de no lesionar al otro derecho absoluto (...) La verdad es que la regla de la bona fides, cuando se refiere a la protección de intereses ya tutelados por un derecho absoluto, comienza a operar cuando termina la tutela del derecho absoluto, y se explica en función de una ulterior específica tutela, constituida en la forma de un vínculo obligatorio" (Mengoni 2011, 281).

El otro argumento sobre el régimen alemán típico de la responsabilidad extracontractual tampoco es obstáculo para negar la aplicación de un régimen semejante a la responsabilidad precontractual en Italia y en Perú:

"las normas (del Código Civil alemán) sobre hechos ilícitos ofrecen solo protección parcial para las hipótesis de daños culposos al patrimonio: el principio contenido en el artículo 823, párrafo $1, B G B$ enumera taxativamente los bienes jurídicos objeto de tutela, entre los cuales no resulta el patrimonio. El párrafo sucesivo del mismo parágrafo admite el resarcimiento por daños al patrimonio, pero con la condición que se viole una norma di protección" (Favale 2013, 884).

En cambio, en Italia y en Perú, la cláusula general de la responsabilidad extracontractual atípica no es una justificación para aplicarla a la responsabilidad precontractual que tiene una lógica diferente. No hay que olvidar que en Alemania el régimen de responsabilidad extracontractual típica también se aplica cuando hay "una lesión de un derecho absoluto contenido en el párrafo 1 del artículo 823 BGB" (Favale 2013, 882). A diferencia de los regímenes de Italia y de Perú, no es admisible sostener que la cláusula general de la responsabilidad extracontractual atípica absorbe a la responsabilidad precontractual como si la responsabilidad por incumplimiento de obligaciones de Italia y la responsabilidad por inejecución de obligaciones en el Perú (según la expresión del Código Civil peruano de 1984) estén en segundo grado. Ello no es así. Ambas responsabilidades regulan intereses diferentes y ello no convierte a la una superior a la otra. No hay que olvidar que "la norma jurídica 'si A, entonces B' es colocada por una decisión humana: o, mejor, por una decisión política, la cual se traduce en figuras típicas y esquemas generales de una determinada valoración de los intereses en juego" (Irti 2016, 141). Cada clase de responsabilidad mantiene su autonomía conceptual y normativa. De ahí que mal se puede colocar a la responsabilidad precontractual en el régimen de la responsabilidad extracontractual por ser atípica cuando existe de por medio una relación obligatoria antes del daño precontractual. Dicho daño se produce por la violación de un deber específico y no por un derecho absoluto ${ }^{(21)}$ oscuro e incomprensible al menos para aplicarla a la responsabilidad precontractual.

Otro argumento de signo de positivismo legalista es el que sostiene una doctrina colombiana:

“más que encontrar 'una' naturaleza de la responsabilidad precontractual, conviene preguntarse en primer lugar sobre el rol del sistema de fuentes de las obligaciones como están planteadas en el ordenamiento jurídico colombiano. La 'tercera especie' de fuente de las obligaciones de Domat y el cuasicontrato de Pothier ciertamente nos invitan a partir de un análisis de las estructuras de nuestra codificación civil antes que tratar de encontrar "una» naturaleza de la responsabilidad precontractual, pues no existe «una» tal naturaleza, o en otros términos: la naturaleza de la responsabilidad precontractual depende de la manera como estén concebidas, ya legal, ya jurisprudencialmente, las «fuentes de las obligaciones» en cada ordenamiento jurídico. Si tuviéramos que definirla, no tendríamos más remedio que describirla como "naturaleza camaleónica»" (Salgado Ramírez 2012, 298) ${ }^{(22)}$.

(21) Un ejemplo de una doctrina nacional que defiende la tesis del deber de buena fe como un deber absoluto: Saavedra Velazco, Renzo E. Op. cit. página 556: "el deber contenido en el artículo 1362 no presenta un carácter positivo, más bien parece configurar un deber general de abstención frente a la esfera jurídica de los sujetos, ello resultaría confirmado por algunos hechos los cuales serían, el derecho que se pretendería tutelar es de carácter absoluto".

(22) En el Perú también se ha sostenido la pertinencia de una disposición normativa que regule las fuentes de las obligaciones para justificar la existencia de una responsabilidad precontractual ajena a la responsabilidad extracontractual: "En efecto, en caso de que se admitiera el valor comúnmente atribuido al artículo 1362, para estos efectos, también habría que conocer, y hacer que cobren arraigo en la praxis del derecho nacional, otros conceptos provenientes de la doctrina alemana, principalmente, la "relación obligatoria sin deber primario de prestación" (u "obligación sin prestación"), las "relaciones de confianza", el "contacto negocial" y los "deberes de protección", y, sobre todo, la idea de la responsabilidad civil que puede deducirse de una relación obligatoria nacida del simple contacto negocial o social, jen un país cuyo Código Civil ni siquiera contiene una norma que señale cuáles son las fuentes de las obligaciones!": León 2017, $703-704$. 
Discrepamos que la responsabilidad precontractual depende cómo se regularon las fuentes de las obligaciones en un Código Civil. En el caso peruano no existe ninguna disposición normativa sobre ellas pero ello no debe impedir el hecho de afirmar que el deber de buena fe regulado en el artículo 1362 del Código Civil peruano de 1984 emana de la ley por un "contacto social calificado" que no requiere estar regulado como fuente de obligaciones ${ }^{(23)}$. Adicionalmente si se revisa el índice del Código Civil peruano de 1984 tampoco será útil. En el Libro VII (Fuentes de las Obligaciones) contiene las secciones primera (Contratos en general); segunda (Contratos nominados); tercera (Gestión de negocios); cuarta (Enriquecimiento sin causa); quinta (Promesa unilateral); y sexta (responsabilidad extracontractual). Sin embargo, hay muchas fuentes de obligaciones que no están en dichas secciones como por ejemplo algunos actos familiares y reales que generan obligaciones. $Y$ nadie puede dudar que ambos actos son fuentes de obligaciones. Lo mismo sucede con el contacto social calificado que nace cuando se inician las negociaciones para celebrar un contrato. $Y$ si se quiere ser positivista legalista, el artículo 1362 del Código Civil peruano de 1984 se refiere claramente a la etapa de negociación. ¿Se puede dudar que en las tratativas no hay "contacto social calificado"? ¿Qué más fuente de obligación es la negociación?

\section{Un caso jurisprudencial peruano antiguo y ajeno a la tesis preponderante de la actual doctrina peruana}

El caso judicial enfrentó a un Grupo peruano contra Daimler Benz A. G. consistió en lo siguiente:

"Como producto de intensa correspondencia telegráfica desde antes del mes de agosto de 1981, la empresa alemana de automóviles Daimler Benz A.G. (conocida mundialmente como Mercedez Benz), acordó, en marzo de 1982, con un grupo de inversionistas peruanos (en adelante "el Grupo Peruano"), otorgarle su representación general en el país, cuando se cumplieran ciertos supuestos obligatorios, como por ejemplo la compra de un terreno de 15,000 metros cuadrados o la adquisición de un importante stock de repuestos. En estricto cumplimiento de los referidos supuestos, el Grupo Peruano incurrió en elevadas inversiones por los más diversos conceptos, teniendo en consideración la importancia económica que significaba asumir la representación en el país de una de las más prestigiosas compañías de automóviles en el planeta. No obstante, ello la empresa alemana consideró inconveniente formalizar el negocio con el Grupo Peruano, decidiendo otorgar su representación a un segundo inversionista. Como consecuencia, el Grupo Peruano recurrió al Poder Judicial peruano para obtener una indemnización, logrando de la Corte Suprema ${ }^{(24)}$ una sentencia favorable" (Falla Jara y Pizarro Aranguren 1991, 96).

En la sentencia ${ }^{(25)}$ expedida por la Tercera Sala Civil de la Corte Superior se señaló que:

"la obligación es un vínculo entre personas naturales jurídicas determinadas en el momento de formarse, o, que deben estarlo al momento de formarse o que deben estarlo al momento de cumplirse. De modo que es entre las personas que la obligación produce sus consecuencias; aún más considerando que las convenciones son bonae fides, en que declina el rigor del derecho, para hacer lugar a la equidad, el uso o la ley que se derivan de ellas; vale decir que los contratantes no tienen necesidad de indicar cuándo contratan las consecuencias derivadas del contrato" (Espinoza 2015, 139).

Lo que merece atención es que se mencionó que la buena fe precontractual rige las tratativas y en el caso concreto hubo negociaciones para celebrar un contrato de mandato con representación, pero la Daimler Benz A.G. rompió las tratativas injustificadamente. La ruptura injustificada de las tratativas:

"constituye ilícita violación de un deber precontractual de buena fe solo con el concurso de dos condiciones. La primera condición es que la ruptura se produzca después que se haya consolidado la justificada confianza de la contraparte en la celebración del contrato (...). La segunda condición es que la ruptura de la tratativa sea injustificada, o como dice la

(23) Absurdamente una doctrina italiana ha declarado que "en ningún lugar del ordenamiento se menciona al contacto social como posible fuente de obligaciones: el «contacto social» representa una fuente extralegal de obligaciones" (Zaccaria, 2013, 94-95). Estas expresiones han merecido una respuesta contundente de otra doctrina: "Jhering había formulado la idea de la responsabilidad precontractual como responsabilidad de naturaleza contractual vinculándola a la buena fe en ausencia de un régimen general” (Castronovo, 2015a, 145). Lo que significa es que, si se considera que una categoría debe estar regulada, cómo se explica que muchas categorías se han creado sin necesidad de una norma expresa. Ello se entiende mejor cuando dicha categoría ya forma parte del derecho viviente.

(24) El texto de la sentencia de 7 de enero de 1991 (expediente № 462-89) emitida por la Corte Suprema está transcrita en: Falla Jara y Pizarro Aranguren 1991, 96-98.

(25) El texto de la Resolución № 2438-5 (Expediente № 1675-88) de 28 de diciembre de 1988 se transcribe en: Espinoza 2015, $137-140$. 
jurisprudencia, privada de «justa causa». La jurisprudencia (italiana) identifica 'la justa causa de la ruptura con una circunstancia externa a la esfera del que se retira, sobrevenida en el curso de la tratativa o preexistente pero por él ignorada sin culpa, idónea para modificar la valoración de conveniencia del contrato"' (Roppo 2009, 186).

En el caso concreto judicial peruano, una parte negociadora incurrió en ruptura injustificada de las tratativas violando el deber precontractual de buena fe a pesar de que ella no estaba regulada textualmente como el actual Código Civil peruano de 1936(26).

La Corte Suprema confundió lo que es una tratativa con un contrato de compromiso de contratar que no estaba regulado en el Código Civil peruano de 1936 y aplicable al caso concreto:

"que estos acuerdos previos en cuanto derivan de un vínculo asumido libre y voluntariamente para regular negociaciones jurídicas patrimoniales, en modo alguno pueden marcarse en el ámbito de la responsabilidad extracontractual, la que por esencia no surge de declaraciones de voluntad sino de circunstancias accidentales que no revelan voluntad de vínculo jurídico entre sujetos, como sí ocurre en el caso de autos; debiendo destacarse además que mientras la responsabilidad extracontractual nace con el daño no querido, en la contractual el daño es provocado por incumplirse la previa relación querida, de manera que en el caso sub-litis no es dable sostener responsabilidad extracontractual ni tampoco culpa pre-contractual o in-contrahendo, toda vez que el télex y las conductas posteriores revelan que las partes ya habían contraído en firme ciertas obligaciones recíprocas de preceptiva observancia conducentes al contrato definitivo, cuyo resarcimiento no puede tener connotación extracontractual cuando el daño deriva de incumplimiento de compromisos; que la inejecución de los mismos no puede en el caso de autos considerarse como actos o conductas faltos de la buena fe que debe presidir las negociaciones, porque el télex en cuestión había puesto fin a las tratativas sobre un contenido ya determinado para el contrato futuro; y por tanto el examen de las conductas debe practicarse en relación con ese contenido cuya existencia no se discute y si él creaba la obligación de firmar el contrato sobre ciertas premisas ya fijadas cuando se cumplieran prestaciones que se admite que se cumplieron, es coherente que el incumplimiento de celebrar el contrato no puede calificarse como culpa leve, por omisión de diligencia debida en la negociación o en la ejecución sino a deliberada intención de no cumplir la obligación asumida para así poder dar cabida en el negocio a un tercero en términos diferentes de los comprometidos con los actores" (Falla Jara y Pizarro Aranguren 1991, 97).

El caso relatado contempló daños en las tratativas para celebrar un contrato de mandato por la ruptura injustificada. No pensamos como lo afirma una doctrina que "el régimen de responsabilidad -al menos, dentro de nuestro sistema- debió y debe ser extracontractual" (Espinoza 2015, 145).

Ahora bien este caso judicial es un buen signo que se puede desarrollar argumentos a pesar de lagunas normativas. La opción para desarrollar adecuadamente el instituto de la responsabilidad precontractual es el formante italiano. Por eso no compartimos el pesimismo de una doctrina nacional cuan/do califica de "indiscutible esterilidad en el Perú de la cláusula normativa general de buena fe consagrada en el artículo 1362 del Código" (León 2017, 705). Esa misma crítica también se podría imputar a la cláusula general de la responsabilidad extracontractual atípica. ¿Cómo una cláusula general no estéril es más conveniente cuando la otra (la cláusula general de la buena fe) es más específica? Ya una doctrina italiana se ha pronunciado sobre la función de la cláusula general de la buena fe: "su 'fisiológica' y su progresiva especificidad ex post en una serie de obligaciones de comportamientos (obblighi comportamentali) (...) que concurren a la 'determinación o determinabilidad objetiva' de su contenido en relación a las exigencias del caso concreto y corroborado también sobre el aspecto obligatorio de la relación" (Turco 2011, 417). Si los italianos pudieron desarrollar la responsabilidad precontractual a partir de algunas pocas normas y sobre todo de su artículo 1337 con el auxilio de una generación extraordinaria de juristas; ¿acaso estamos condenados a no empezar el mismo camino que emprendieron ellos? Seguramente estamos en desventaja por varios factores como la educación jurídica en el Perú influenciada por metodologías ajenas al Derecho; la poca investigación jurídica de los profesores; la indiferencia del Estado de proporcionar recursos a las universidades estatales y a las instituciones de la administración de justicia; la proliferación de universidades privadas sin recursos bibliográficos de primer nivel jurídico y profesores prácticos; la corrupción generalizada que corroe las instituciones privadas y públicas; las nuevas especialidades jurídicas que desnaturalizan el Derecho Civil; ausencia de conocimiento de categorías del Derecho Civil en muchas sentencias emanadas de la Corte Suprema, entre otros. Claro que

(26) La buena fe precontractual no estaba regulada expresamente en la ley vigente aplicable al caso concreto. Solo se reguló -en la época que se produjo el caso- la buena fe en la ejecución del contrato: Artículo 1328 del Código Civil peruano de 1936.- Los contratos son obligatorios en cuanto se haya expresado en ellos, y deben ejecutarse según las reglas de la buena fe y común intención de las partes. 
estamos en desventaja pero eso no nos puede amilanar para construir una cultura jurídica propia y respetada como algunos de nuestros países latinoamericanos.

\section{Esta doctrina peruana propone:}

"que el verdadero sustento legal de la responsabilidad precontractual en nuestro medio es, como en Francia, la cláusula normativa general en materia de responsabilidad nacida de acto ilícito, es decir, el artículo 1969. Con mayor razón, porque en nuestro Código Civil, el descargo por falta de dolo o culpa corresponde al autor del acto ilícito (según la segunda parte del artículo 1969); peculiaridad de la normativa peruana que resulta decisiva, a la larga, porque una de las razones que mueven a desconfiar del esquema francés (que, como se ha visto, crea la responsabilidad precontractual a partir de la responsabilidad delictual) es, precisamente, la exigencia de la prueba de la culpa, que según el derecho galo tiene que correr por cuenta de la víctima del daño extracontractual. Esta solución sería la única coherente, así mismo, con algo de lo que todos debemos ser conscientes: la necesidad de evolucionar progresivamente, difundiendo ideas realizables y creando convicciones sobre éstas, y no dando saltos conceptuales, en el vacío, ni procediendo por imitación, con el solo soporte de la lectura superficial de una norma jurídica importada en 1984 (y de la bibliografía de su país de origen), acaso con el puro afán de mantener a la moda el Código Civil” (León 2017, 706).

Estimamos que la propuesta olvida que la cláusula general de la responsabilidad extracontractual atípica es impotente para transformar deberes genéricos absolutos en deberes específicos precontractuales de buena fe; o reducir los deberes precontractuales que emanan de la buena fe a un deber de diligencia. Precisamente, el artículo 1362 del Código Civil peruano de 1984 regula una cláusula general de buena fe que permite desarrollar la justicia contractual la cual "indica una necesidad del sistema que establece límites de una mutación esencialmente intrínseca a la dinámica de la relación prenegocial y de aquella contractual: también adquieren relevancia elementos del contexto, como por ejemplo la disparidad de fuerzas entre las partes o la situación de dependencia económica, los factores externos a la relación entre sujetos involucrados asumen el rol exclusivo de un terreno de cultivo de las conductas contrarias a la buena fe" (Piraino 2015, 292). Los incumplimientos de deberes precontractuales del empresario en la fase decisoria del consumidor de celebrar contratos de consumo no pueden resolverse mediante una cláusula general de responsabilidad atípica. Es cierto que la presunción de la culpa leve ${ }^{(27)}$ en la responsabilidad por inejecución de obligaciones en el Código Civil peruano de 1984 es una desventaja a diferencia de la presunción de dolo o culpa de la segunda parte del artículo 1969. Sin embargo, en cuanto a los plazos de prescripción, es más conveniente el plazo de 10 años (numeral 1 del artículo 2001 del
Código Civil peruano de 1984) para el régimen de la responsabilidad por inejecución de obligaciones que el plazo de 2 años (numeral 4 del artículo 2001 del Código Civil peruano de 1984) para el régimen de la responsabilidad extracontractual. Así las cosas, al menos en los dos rubros mencionados, hay paridad.

Por otro lado, La cláusula general de la responsabilidad extracontractual atípica es reduccionista frente a la justicia contractual. De ahí, por citar un remedio, que las disposiciones normativas sobre responsabilidad obligacional (o contractual) -y no las de responsabilidad extracontractual- sirven adecuadamente para desarrollar la justicia contractual conjuntamente con la buena fe objetiva en las etapas no solo de celebración y ejecución del contrato sino también en las de negociación y post contractual. Nadie puede dudar que el derecho civil francés es extraordinario por sus aportes (como la solidaridad contractual) pero es un ordenamiento desconocido en el medio académico y profesional del Perú. La bibliografía actual del derecho civil francés en las facultades de derecho en el Perú es casi inexistente. No se invitan frecuentemente a los profesores franceses como, por ejemplo, sí sucede en Colombia y Brasil, para conocer su desarrollo jurisprudencial y doctrinario. Muy pocos estudian posgrados en las universidades francesas. Este desconocimiento no es un problema para seguir el modelo que se propone. No obstante, en Francia la responsabilidad precontractual no se ha desarrollado doctrinal ni jurisprudencialmente como en Italia. En la experiencia francesa existe "una tendencia que la responsabilidad aquiliana todo lo abarca incluso respecto a aquella contractual" (Castronovo 2015b, 527). En Francia, "las negociaciones precontractuales no son un verdadero contrato, la jurisprudencia juzga que esta responsabilidad precontractual sólo puede ser de naturaleza delictiva" (Cabrillac 2016, 47). Y las facultades de derecho -algunas- en el Perú han recibido la enseñanza del derecho civil italiano, el cual no es menos prestigioso que el francés, por más de una década. Muchos profesores latinoamericanos estudiaron en universidades italianas y al retorno han desarrollado en sus lecciones y en sus escritos algunas de las doctrinas de ese país. Un ejemplo es una doctrina colombiana:

(27) Artículo 1329 del Código Civil peruano de 1984.- Se presume que la inejecución de la obligación, o su cumplimiento parcial, tardío o defectuoso, obedece a culpa leve del deudor. 
"Complementariamente ha de observarse que dicha responsabilidad no emana de la violación de un deber genérico, o de la lesión de un derecho 'absoluto'; se asienta en una relación concreta, no contractual, pero no menos cierta, entre los intervinientes en las negociaciones, lo que se pone de presente en la propia individualización de la categoría 'precontractual', por lo demás inexpresiva o, mejor, elusiva. Caracteres propios que han permitido afirmar que se trata de un tercer género, en el que se encuadrarían los supuestos de hecho de violación de obligaciones (legales) que por no ser contractuales, no parecen encontrar sitio adecuado en la llamada responsabilidad 'contractual'” (Hinestrosa 2015, 402).

Estas aseveraciones se basan en un sector de la doctrina italiana $^{(28)}$. El problema es si se puede transmitir y aplicar algunos pensamientos jurídicos a una realidad como la peruana. Fuera de los factores señalados y yendo a lo técnico, estimamos que una aplicación de la responsabilidad extracontractual a la responsabilidad precontractual genera problemas de aplicación y deja sin contenido a la buena fe objetiva. Por ello, estimamos que la responsabilidad precontractual tiene autonomía conceptual que difiere enormemente de la responsabilidad extracontractual y se aproxima a la responsabilidad por inejecución de obligaciones (pero sin reducirse a ella).

\section{La responsabilidad precontractual es un tipo de responsabilidad por incumplimiento de obligaciones sin prestación}

Sin duda la responsabilidad precontractual tiene dos criterios que la fundamentan: obligación sin prestación y confianza.

La categoría de la obligación sin prestación es una obligación autónoma "desde el momento que se inician las tratativas" (Castronovo 1999, 693). Esta obligación sin prestación emana de la buena fe integrativa. Así, una doctrina italiana propuso ubicar la responsabilidad precontractual en los términos de una relación obligatoria individualizada mediante la extensión, a la fase de las tratativas y de la formación del contrato" (Mengoni 2011, 272) en base al artículo 1175 del Código Civil italiano de 1942. En consecuencia, la categoría relación obligatoria es compleja en el sentido que junto:

"a la obligación (obbligo) principal que tiene por objeto la prestación hay otras obligaciones (obblighi) accesorias, que son funcionales a la satisfacción de los intereses de ambas partes. En efecto, se establece el artículo 1175 c.c. que el deudor y el acreedor deben comportarse según las reglas de lealtad (corretteza). Por eso, la norma prevé obligaciones (obblighi) de lealtad (corretteza) a cargo de ambas partes de la relación obligatoria, incluso para el acreedor. Se trata de obligaciones (obblighi) diversas de aquella de prestación, que grava solo sobre el deudor. La ley no establece cuáles son tales obligaciones (obblighi), pero confía tal tarea al juez, que lo determina según el mecanismo de las cláusulas generales. La lealtad (corretteza) (1175 c.c.) en este caso es sinónimo de buena fe objetiva (1375 c.c.) y se aplica como fuente de reglas de comportamiento que no están expresamente previstas por la ley o por las partes, pero son elaboradas por el juez sobre la base de estándares (standards) y parámetros de valoración deducidos del contexto social" (Albanese 2014, 15-16).

La categoría de la "relación obligatoria compleja" se aplicó en Brasil a través de la categoría de la "relación obligatoria como proceso". Tal "teoría formulada por Clóvis do Couto e Silva proporciona más argumentos para la defensa de la naturaleza obligacional de la responsabilidad civil precontractual" (Pereira 2017,149). Una doctrina italiana ha resaltado que la categoría de la "obligación sin prestación" "es una hipótesis dogmática fundada y creíble" (Piraino 2017, 52) porque tiene aplicaciones muy concretas y aceptadas por el tráfico jurídico internacional: "la custodia de los bienes de la contraparte puestos a disposición del otro contratante en el desarrollo de la tratativa y de la celebración del contrato; la preservación de la integridad física del otro contratante; la conservación de la reserva sobre las informaciones reveladas a la contraparte o adquiridas en el transcurso de la contratación; el aviso sobre la existencia de causales de invalideces del contrato antes del perfeccionamiento (artículo $1338{ }^{(29)}$ c.c.)" (Piraino 2017, 53).

El otro criterio de la responsabilidad precontractual es la confianza. No importa que la confianza no esté positivizada: "Por otro lado, es justo recordar que la protección de las

(28) Cuffaro. voz "Responsabilità precontrattuale". En: Enciclopedia del diritto. XXXIX. Milán: Giuffrè. 1988. página 1267 y siguientes. Rescigno. voz "Obbligazion. Nozione”. En: Enciclopedia del diritto. XXX. Milán: Giuffrè. 1979. página 148 y siguientes. Sapone. La responsabilità precontrattuale. Milán: Giuffrè. 2008. página 102 siguientes.

(29) Artículo 1338 del Código Civil italiano de 1942. Conocimiento de las causas de invalidez.- La parte que conociendo, o debiendo conocer la existencia de una causa de invalidez del contrato, no da noticia de ello a la otra parte queda obligada a resarcir el daño causado a ésta, por haber confiado, sin su culpa, en la validez del contrato. 
confianzas atípicas pertenece no solamente al derecho escrito, sino también a la reflexión del jurista" (Sacco 2005, 431). Una doctrina italiana afirma que "la 'confianza objetiva' es extrínseca a la fattispecie del artículo 1337, la tratativa y el tipo de conflicto que genera constituyen el único terreno sobre el cual se puede realizar correctamente la analogía" (Barcellona 2011, 88). Y esta doctrina aplica la analogía a las "situaciones de interferencia que paradigmáticamente son consideradas y resueltas por el artículo 2043" (Barcellona 2011, 89). El contacto social que produciría la responsabilidad extracontractual no es calificado sino un contacto simple porque tanto el dañador como el damnificado no están enlazos en una relación jurídica a diferencia de un "contacto social calificado" donde sí existe una relación que contiene deberes impuestos a los sujetos involucrados. Esta categoría del "contacto social calificado" ha sido consagrada en la Casación Civil italiana, Sez. I, 12 de julio de 2016, n. 14188. En el Fundamento 12.1 de esta sentencia describe qué se entiende por contacto social calificado:

"el contacto social entre esferas jurídicas diversas debe ser 'calificado', el cual se caracteriza por un 'propósito' (scopo) según el cual las partes tienen la intención de perseguir. En virtud de tal relación calificada, una persona -con el fin de lograr un objetivo determinado (estipular un contrato no desventajoso, evitar eventos perjudiciales a la persona o al patrimonio, asegurarse el correcto ejercicio de la acción administrativa)- confía sus propios bienes de la vida a la lealtad (correttezza), a la influencia y a la profesionalidad de otra persona. Así, como es de todo evidente no es una hipótesis de mero contacto social, sino de un contacto social que se convierte fuente de responsabilidad -concretando un hecho idóneo para producir obligaciones según el artículo $1173^{(30)}$ del Código Civil: en virtud de una confianza recíproca de las partes y del consecuente inicio de específicas, y recíprocas, obligaciones (obblighi) de buena fe, de protección y de información". Esta jurisprudencia italiana se adhiere a una doctrina italiana: "El modelo de la jurisprudencia italiana es claramente la teoría de Carlo Castronovo: hay una relación diversa de aquella contractual, pero hay un 'propósito' (scopo) y, en relación a ello, una confianza recíproca entre las partes" (Varanese 2018, 139).

Otra doctrina italiana enriquece este punto de vista al sostener que una vez colacada la "obligación sin prestación" a partir de las características de la relación precontractual, es necesario aclarar que tal categoría es plausible en cuanto la 'culpa in contrahendo' se entienda como responsabilidad relacional, es decir, como mecanismo de traslación del costo de los daños que se generan al interior de una relación a causa de la violación de reglas específicas de conducta o de la superación de los límites de la acción" (Piraino 2017, 61).

La buena fe y la confianza "están específicamente coordinadas, y en sentido opuesto, de la confianza a la buena fe como del hecho al derecho, en cuanto el surgimiento de la confianza produce la buena fe, ésta última se convierte en fuente de obligaciones de protección" (Castronovo 1999, 695). Aquí sí es pertinente decir que hay contacto social en función de la confianza "como en la responsabilidad precontractual tal elemento está constitutido por la cualidad de parte que la ley atribuye a los sujetos en tratativa, cualidad sin la cual no se explica la obligación de comportarse según la buena fe" (Castronovo 1999, 698). De ahí que se protege "la buena fe y la confianza que la parte depositó en la declaración del otro contratante" (Marques 2016, 283).

La confianza "desarrolla un rol esencial al individualizar ex ante los comportamientos que las partes deben cumplir en las tratativas" (Albanese 2017, 1145). En efecto, la confianza es el fundamento de la responsabilidad precontractual y una doctrina portuguesa sigue esta tendencia:

"En general y en el esquema, la tutela de la confianza depende de la coexistencia de los siguientes elementos:

- Una situación de confianza efectiva e imputable a determinada persona (imputación de confianza);

- Justificación de confianza basada por datos objetivos y creíbles

- Inversión por la confianza, causada por ella y traducido en actos concretos y externos, con o sin expresión financiera inmediata

- Buena fe de quien confío" (Ferreira de Almeida 2005, 200).

También en Brasil, una doctrina importante señala que "por la teoría de la confianza, hoy mayoritaria, se admite la responsabilidad de quien, por su comportamiento en la sociedad, hace nacer en el otro contratante la justificada expectativa en el cumplimiento de determinadas obligaciones" (Marques 2016, 218-219). Estas expresiones son perfectamente aplicables a los contratos de consumo donde la confianza adquiere un rol ineludible: "La confianza se convierte en último análisis para el derecho, el mercado debe ser un lugar seguro, donde pueda existir armonía

(30) Artículo 1173 del Código Civil italiano de 1942. Fuentes de las obligaciones. Las obligaciones derivan de contrato, de hecho, ilícito o de cualquier otro acto o hecho idóneo para producirlas, de conformidad con el ordenamiento jurídico. 
y lealtad en las relaciones entre consumidores y empresarios y donde no se necesite siempre 'desconfiar' del otro" (Marques 2016, 289).

Así las cosas, una doctrina portuguesa indica para aplicar la cláusula para:

"merecer protección del régimen del artículo 227 (norma semejante al artículo 1362 del Código Civil peruano de 1984), debe, por lo tanto, el damnificado haber confiado e invertido en la confianza justificadamente creada. Conforme a los casos, deberá haber confiado en la validez y en la eficacia del contrato, que al final era inválido o ineficaz, o había confiado en la celebración del contrato, que al final no se llegó a formar, o confío en el equilibrio de un contrato, que al final estaba desequilibrado. Sobre otro punto de vista (conforme el deber violado), la confianza del lesionado deberá haberse basado en la información proporcionada, que no era al final correcta, o en la lealtad del otro contratante, que al final no prosiguió o concluyó las negociaciones, o el secreto que la otra parte no guardó, o en la diligencia que ella no usó en el modo cómo se expresó o en la atención que prestó" (Ferreira de Almeida 2005, 201).

Este estudio defiende la tesis que la responsabilidad precontractual es ajena a la responsabilidad extracontractual. De ahí es importante reivindicar a una doctrina peruana que sí defendió esta tesis:

"el deber de proceder según las reglas de la buena fe se impone a los tratantes, o sea a quienes han decidido establecer cierto vínculo entre sí para explorar juntos las posibilidades de celebrar un contrato. No cabe, pues, ubicar la responsabilidad por el incumplimiento de ese deber en el campo de la responsabilidad por acto ilícito, desde que no se trata de la violación de un deber genérico de no dañar, que es el fundamento de esta responsabilidad, sino de la violación de un deber específico del uno frente al otro asumido voluntariamente por los tratantes al dar inicio a las tratativas" (De la Puente y Lavalle 2007, 369).

Es claro que las partes negociadoras están unidas a través de una relación jurídica. Uno de los fundamentos de esta relación es el deber de buena fe objetiva. Esta buena fe objetiva es "una regla de conducta. Como criterio de comportamiento de las partes en la fase de negociación, la buena fe se traduce en el deber de actuar honesta, leal y transparentemente, como una persona de bien" (Pais de Vasconcelos 2005, 328). Seguidamente es "necesaria una referencia a los modelos de comportamiento aceptable y exigible vigentes en la sociedad, en el círculo de personas y de actividades en que el contrato se desarrolla, o en los usos propios o típicos de negociación y de celebración de aquél contrato" (Pais de Vasconcelos 2005, 328).

De este modo se tutela directamente la confianza fundada de cada una de las partes en que la otra conduzca las negociaciones según la buena fe; $\mathrm{y}$, por consiguiente, las expectativas legítimas que la misma cree, no solamente en cuanto a la validez y eficacia del negocio, sino también en cuanto a su futura celebración. En efecto, las partes negociadoras:

"no solamente deben tener una simple actitud de lealtad, traducida en obligaciones de propósito negativo -aunque el contenido de ellas puede consistir en 'no hacer' o en un 'hacer'-, dirigidas apenas a impedir toda lesión en la esfera jurídica del otro; también deben tener una colaboración activa, en el sentido de satisfacción de las expectativas ajenas, que exige el conocimiento real de la situación que constituye objeto de las negociaciones. Se refiere, en resumen, a los dos aspectos, el negativo y el positivo, que se acostumbra distinguir en el ámbito de la buena fe objetiva" (Almeida Costa 2006, 275-277).

Una doctrina italiana prefiere usar otro criterio diferente a la confianza: la inmunidad: "Así, se trata de una situación jurídica de ventaja que garantice al titular una tutela reforzada contra los daños respecto a aquella" (Piraino 2017, 57). En consecuencia, la "inmunidad se revela perfectamente coherente con la individualización del fundamento de la responsabilidad precontractual en la proximidad intencional de las esferas jurídicas de los contratantes y en el incremento del riesgo recíproco de dañar a la otra parte de la relación" (Piraino 2017, 57-58). Nos parece muy clara la propuesta de esta doctrina en el sentido que las relaciones obligatorias precontractuales incluirían dos situaciones jurídicas subjetivas: una de inmunidad y la otra de la obligación sin prestación. ¿Se podría prescindir de la confianza con esta propuesta? En nuestra opinión, hay una complementariedad entre la confianza y las situaciones jurídicas subjetivas que ella genera.

Así las cosas, el "modelo de la obligación sin prestación puede dar una explicación convincente de la relación existente entre las partes en la culpa in contrahendo, que evoca un contacto 'negocial' o 'social calificado'" (Varanese 2018, 140).

\section{Conclusiones}

Entonces, la responsabilidad precontractual es un remedio diferente de la responsabilidad por incumplimiento total; y cumplimiento parcial, tardío o defectuoso; y de la responsabilidad extracontractual. El carácter autónomo de la responsabilidad precontractual se explica por los diferentes intereses resarcibles que 
protege. El instituto de la responsabilidad precontractual explica la inexistencia de una matriz única de la responsabilidad civil porque según esta idea le corresponden los mismos requisitos como fue mencionado en el Fundamento Octavo de la Casación 4407-2015-Piura de 05 de mayo de 2016 emitida por la Sala Civil Permanente de la Corte Suprema de Justicia de la República del Perú sobre un caso de responsabilidad precontractual. Por el contrario, cada clase de responsabilidad (precontractual; obligacional; post contractual y extracontractual) responde a lógicas diferentes y a remedios independientes. Desde el punto de vista de una idea de que:

"el contrato es como un proceso (una sucesión de 'tiempos' como ocurre con el propio negocio jurídico), que se inicia desde la fase precontractual, pasando por la fase contractual, distribuida en tres fases menores (celebración del contrato, eficacia del contrato y ejecución/ cumplimiento del contrato) y hasta la fase postcontractual, todas subordinadas a la buena fe objetiva, pensamos que, aunque se produzca un acto ilícito, la responsabilidad precontractual, por tratarse de incumplimiento de deberes específicos, generados por la buena fe objetiva, se debe someter al tratamiento de la responsabilidad contractual" (Azevedo 1995, 123).

En este orden de ideas, la responsabilidad precontractual solo cabe entenderla en la consecución de un objetivo: la celebración de un contrato. Aunque no se logre celebrarlo, los intereses dignos de tutela tendrán que tomar en cuenta las expectativas de las partes negociadoras, de sus confianzas y de sus frustraciones. También cabe la posibilidad que los contratos se celebren, pero en las negociaciones se produjeron lesiones a los intereses de algunas de las partes negociadoras. En este sentido, "la buena fe cumple una función de límite de la libertad individual. Sin embargo, la relación jurídica precontractual persigue por la variedad de contenidos, una finalidad, o si se prefiere, una función unitaria y compleja, que se sustenta en el objetivo de la salvaguardia y de respeto (Rücksicht) del patrimonio y de la esfera personal de los contratantes, de modo que la buena fe termina por imponer comportamientos dirigidos a promover la celebración de un contrato válido, eficaz y apoyado de elecciones libres y conscientes, su horizonte de sentido total se sustenta en todo caso en proteger la esfera jurídica de la contraparte" (Piraino 2017, 55). Ahora se entiende la razón del inigualable jurista privatista brasileño, Pontes de Miranda, quien "defendió la existencia de un deber de protección en las negociaciones, autónomo en relación al deber general de no causar daño" (Nunes Fritz y Karina 2012, 13).

La laguna del artículo 1362 del Código Civil peruano de 1984 en cuanto a la falta de regulación del efecto no debe ser un obstáculo para desarrollar en el futuro el instituto de la responsabilidad precontractual bajo la cláusula general de la buena fe:

"El vacío de la ley no es un defecto, en contra de lo que sostiene la concepción positivista, sino que es a prioiri y necesario. La ley no puede y no debe ser formulada en forma unívoca, pues se crea para todos los casos, cuya multiplicidad es infinita. Una ley cerrada en sí misma, completa, sin vacíos, clara (en la medida en que algo así fuese posible), conduciría el desarrollo del derecho al estancamiento. Esto es también importante para el lenguaje de la ley. Fuera de los pocos casos de conceptos numéricos, los conceptos legales no son inequívocos, no son conceptos abstractos-generales sino conceptos tipo, conceptos de orden, en los cuales no existe la disyunción estricta, sino el más o el menos" (Kaufmann 2005, 193).

Preguntemos qué hicieron los brasileños antes de la vigencia de su actual Código Civil cuando no tenían una disposición normativa similar a la peruana o a la italiana. Como bien dice una doctrina brasileña: "los jueces brasileños iniciaron la construcción de los casos de la responsabilidad precontractual en base al principio de la buena fe objetiva y en el deber de protección de las legítimas expectativas de los contratantes y de los precontratantes" (Martins-Costa 2002, 83).

Sin embargo, existe en el Perú una propuesta normativa -si es aprobada por el Congreso de la República o por el Poder Ejecutivo si tiene poderes delegados por el Poder Legislativo- que elimina la laguna actual. El Anteproyecto de Reforma al Código Civil peruano y Propuestas de Mejora presentado en junio de 2018 ante el Ministerio de Justicia y Derechos Humanos de la República del Perú por el Grupo de Trabajo Revisión y Mejoras al Código Civil creado por la Resolución Ministerial 0300-2016-JUS y modificatorias, propone una disposición normativa que suple la laguna actual: "Artículo 1362-A. Responsabilidad precontractual.- El incumplimiento imputable de un deber precontractual generará la obligación de la parte infractora de indemnizar los daños que se generen a su contraparte". La exposición de motivos de esta propuesta indica lo siguiente: "En la práctica judicial y arbitral se han incrementado los casos de responsabilidad precontractual, amparándose únicamente en el artículo 1362 del Código Civil. Por ello, el Grupo de Trabajo propone incluir este artículo para regular de manera expresa la responsabilidad precontractual y la obligación de indemnizar los daños que ocasione la parte infractora" (página 142).

Nos adherimos a esta propuesta. Pero todavía queda la incertidumbre natural sobre 
qué régimen se aplicará: o el régimen de responsabilidad por inejecución de obligaciones o el régimen de responsabilidad extracontractual del Código Civil peruano de 1984. Nos adherimos que el régimen aplicable es el de la responsabilidad por inejecución de obligaciones por cuanto la cláusula general de la buena fe es superior a la cláusula general de la responsabilidad extracontractual por su especificidad de los deberes precontractuales que emanan de la buena fe en su sentido objetivo.

Sin duda en los "variados ordenamientos jurídicos, cuestiones referentes a los límites resarcitorios, a los plazos de prescripción o, lo mismo, a la carga de la prueba se revelan diferentes si son analizadas bajo la perspectiva de cada una de las tipologías de la responsabilidad civil identificadas por la Ciencia Jurídica" (Pereira 2017, 130).

Sin embargo, la naturaleza de la responsabilidad precontractual es compatible con un régimen de responsabilidad por incumplimiento de obligaciones. Una doctrina colombiana explica esta virtud:

"Por ello no es adecuado ubicar la responsabilidad precontractual en vía aquiliana. El ámbito delictual se encuentra tendencialmente conformado y armonizado con las normas de naturaleza general, básicas, y dirigidas a regular las normas de convivencia universal, por tanto, no pueden aplicarse dichas reglas en el mundo de los contratos, así estemos ante su propia formación, aquí ya no hablamos de normas de intersección humana generales, sino concretas, que requieren ponderaciones específicas por el vínculo que une a las partes que intentan negociar, como lo es corrección. Entonces, no tiene mucho sentido que incluso quienes defienden posiciones aquilianas, afirmen que la etapa de la formación contractual debe caracterizarse por el comportamiento acorde a la corrección y a los usos habituales del tráfico jurídico, puesto que estos conceptos están relacionados exclusivamente con el mundo de las obligaciones contractuales. En el marco de la responsabilidad contractual, el daño se da entre personas que se conocen (aquí el daño se da en miras a la formación de un contrato), ¿cómo entonces al tenor de la norma del $1902^{(31)}$, se explica aquí la conducta culpable cuando en los tratos preliminares las partes gozan de libertad contractual? ¿Cómo explicar que de conformidad con las normas de la buena fe in contrahendo, existen toda una cantidad de deberes secundarios de conducta? Frente a los deberes secundarios, se disponen obligaciones positivas (información, conservación) y negativas (secreto, y no ejercer acciones que dañen el interés ajeno). ¿Acaso, cuándo se falta a ellas no se está frente al incumplimiento de un deber u obligación predeterminado? Son éstos sin duda cuestionamientos que nos llevan a inclinarnos, por una postura eminentemente contractual al momento de establecer la naturaleza jurídica de la responsabilidad originada por la ruptura injustificada de las negociaciones" (Monsalve Caballero 2014, 352).

Nos adherimos a las palabras de esta doctrina colombiana porque se sustenta en la pluralidad de deberes precontractuales que emanan de la buena fe objetiva; y dicha pluralidad no puede ser explicada por la cláusula general de la responsabilidad extracontractual atípica. En Brasil a pesar de la confusa redacción del artículo $187^{(32)}$ del Código Civil dentro de la sección de los Actos llícitos, una doctrina afirma "que el régimen para la solución de la mayor parte de las controversias surgidas en la fase precontractual es de la responsabilidad contractual, en razón de las innumerables características que permiten un tratamiento más acorde con la realidad de los acontecimientos en la fase de la formación" (Pereira 2017,168). ¿Y en el Perú qué esperamos para darle funcionalidad a la buena fe objetiva en la responsabilidad precontractual? Miremos cómo algunos italianos, portugueses, brasileños y colombianos han desarrollado la categoría de la buena fe objetiva. Ya lo hizo una jurisprudencia peruana en la década de los ochenta. Estamos en el Siglo XXI. Nos queda el reto de continuar el desarrollo propuesto en este estudio para salvaguardar intereses precontractuales dignos de tutela. El otro camino será lo que existe hoy en la práctica forense y en la práctica jurisdiccional en el Perú: desconocimiento de los remedios precontractuales por parte de abogados, árbitros y jueces.

\section{Referencias bibliográficas}

Albanese, Antonio. 2014. I/ rapporto obbligatorio: Profili strutturali e funzionali. Roma: Libellula Edizioni. 2017. La lunga marcia della responsabilità precontrattuale: Dalla culpa in contrahendo alla violazione di obblighi di protezione. En: Europa e diritto privato. №3, 1129-1148. Milán: Giuffrè Editore.

(31) Artículo 1902 del Código Civil español de 1889. El que por acción u omisión causa daño a otro, interviniendo culpa o negligencia, está obligado a reparar el daño causado.

(32) Artículo 187 del Código Civil brasileño de 2002. También incurre en acto ilícito el titular de un derecho que, al ejercerlo, excede manifiestamente los límites impuestos por su fin económico o social, por la buena fe o por las buenas costumbres. 
Almeida Costa, Mário Júlio de. 2006. Direito das obligações. $9^{a}$ Edição revista e aumentada. Coimbra: Almedina.

Azevedo, Antonio Junqueira de. 1995. Responsabilidade pré-contratual no Código de Defesa do Consumidor: estudo comparativo com a responsabilidade pré-contratual no direito comum. En: Revista da Faculdade de Direito da Universidade de São Paulo. Volumen 90,121-132. https://doi.org/10.11606/ issn.2318-8235.v90i0p121-132

Barcellona, Mario. 2011. Trattato della responsabilità civile. Turín: Utet Giuridica.

Benatti, Francesco. 1991. Voz Responsabilità precontrattuale: Diritto civile. En: Roma: Enciclopedia Giuridica Treccani. Volumen XXVII,1-11 (de la separata).

Bianca, C. Massimo. 2007. Derecho Civil. El contrato. Traducción de Fernando Hinestrosa y Édgar Cortés. III. 2da edición. Bogotá: Universidad Externado de Colombia.

Breccia, Umberto; Bruscuglia, Luciano; Busnelli, Francesco Donato; Giardina, Francesca; Giusti, Alberto; Loi, Maria Leonarda; Navarretta, Emanuela; Paladini, Mauro; Poletti, Dianora y Zana, Mario. 2010. Diritto privato. Tomo Secondo. Seconda Edizione. Turín: Utet Giuridica.

Cabrillac, Rémy. 2016. Droit européen comparé des contrats. 2e édition. Paris: LGDJ.

Castronovo, Carlo. 2009. Ritorno all'obbligazione senza prestazione. En: Europa e diritto privato. № 3, 679-717. Milán: Giuffrè Editore.

2015a. Eclissi del diritto civile. Ristampa emendata. Milán: Giuffrè Editore.

2015b. "Sul significato di 'materia contrattuale' e 'materia di illeciti civili' nelle fonti europee relative alla competenza giurisdizionale". En: Europa e diritto privato. № 3, 517-543. Milán: Giuffrè Editore.

Escobar Rozas, Freddy. 2004. Apuntes sobre la responsabilidad por ineficacia contractual (el caso del artículo 207 del Código Civil peruano). En: THËMIS-Revista de Derecho 49, 153-160. Lima.

Espinoza Espinoza, Juan. 2012. Acto jurídico negocial, Análisis doctrinario, legislativo y jurisprudencial. Tercera edición. Lima: Gaceta Jurídica.

2015. Un curioso caso de responsabilidad civil precontractual peruano. En: Gaceta Civil \& Procesal Civil. N ${ }^{\circ} 20$, 137-145. Febrero. Lima: Gaceta Jurídica.

De La Puente y Lavalle, Manuel. 2007. El contrato en general. Comentarios a la sección primera del libro VII del Código Civil. Segunda reimpresión de la segunda edición actualizada. Tomo I. Lima: Palestra.

Falla Jara, Alejandro y Pizarro Aranguren, Luis. 1991. El problema de los diminutos montos indemnizatorios: dos casos ejemplares y esperanzadores. En: THËMIS-Revista de Derecho, 96-102. $\mathrm{N}^{\circ}$ 20. Lima.
Favale, Rocco. 2013. II sistema dell'Anwaltshaftung nel modello tedesco. En: Contratto e impresa/Europa. № 2. JulioDiciembre, 850-887. Padua: Cedam.

Ferreira de Almeida, Carlos. 2005. Contratos. Conceito. Fontes. Formação. I. $3^{a}$ Edição. Coimbra: Almedina.

Hinestrosa, Fernando. 2015. Tratado de las obligaciones. II. De las fuentes de las obligaciones: El negocio jurídico. Volumen I. Bogotá: Universidad Externado de Colombia.

Hörster, Heinrich Ewald. 2005. A parte geral do Código Civil Português. Teoria Geral do Direito Civil. Coimbra: Edições Almedina.

Irti, Natalino. 2016. Un diritto incalcolabile. Turín: G. Giappichelli Editore.

Kaufmann, Arthur. 2005. Filosofía del derecho. Traducción de Luis Villar Borda y Ana María Montoya. Bogotá: Universidad Externado de Colombia.

León, Leysser L. 2017. La responsabilidad civil. Líneas fundamentales y nuevas perspectivas. Tercera edición corregida y aumentada. Lima: Pacífico Editores.

Lipari, Nicolò. 2013. Le categorie del diritto civile. Milán: Giuffrè Editore.

Marques, Claudia Lima. 2016. Contratos no Código de Defesa do Consumidor: o novo regime das relações contratuais. 8. Edición Rev., attual. e ampl. San Pablo: Editora Revista dos Tribunais.

Martins-Costa, Judith. 2002. A boa-fé como modelo (Notas para a compreensão da boafé obrigacional como modelo doutrinário e jurisprudencial no direito brasileiro). En: Roma e America. Diritto Romano Comune. Rivista de Diritto dell'Integrazione e Unificazione del diritto in Europa e in America Latina. 13, 71-97. Roma: Mucchi Editore.

Mattei, Ugo y Monateri, Pier Giuseppe. 1997. Introduzione breve al diritto comparato. Padua: Cedam.

Menezes Cordeiro, António. 2010. Tratado de direito civil portugués. II. Direito das obrigações. Tomo III. Gestão de negócios, Enriquecimento sem causa, Responsabilidade civil. Coimbra: Edições Almedina.

Mengoni, Luigi. 2011. Sulla natura della responsabilità precontrattuale. En: Scritti. Obbligazioni e negozio. Bajo la dirección de 
Carlo Castronovo, Antonio Albanese y Andrea Nicolussi. Volumen I. Milán: Giuffrè Editore.

Monateri, Pier Giuseppe. 2004. La responsabilidad precontractual en el ordenamiento italiano. En: AA. VV. Estudios sobre el contrato en general. Selección, traducción y notas de Leysser L. León. Segunda edición. Lima: ARA Editores.

Monsalve Caballero, Vladimir. 2014. Responsabilidad precontractual. La ruptura injustificada de las negociaciones. Bogotá: Grupo Editorial Ibáñez.

Morales Hervias, Rómulo. 2013. "Los contratos con deberes de protección: a propósito de la vinculación entre el derecho constitucional y el derecho civil". En: Derecho PUCP Revista de Derecho, número 71, 53-71. Lima: Fondo Editorial de la Pontificia Universidad Católica del Perú.

2015. "Los contratos con deberes de protección: a propósito de la vinculación entre el derecho constitucional y el derecho civil". Revista da Ajuris, Revista de los Jueces de Río Grande del Sur, Volumen 42, número 139., 285311. http://www.ajuris.org.br/OJS2/index.php/ REVAJURIS/article/view/575/Ajuris139_DT12. pdf (Consulta: 17 de noviembre de 2018).

Nunes Fritz, Karina. 2012. A responsabilidade pré-contratual por ruptura injustificada das negociações. En: Civilistica.com. Rio de Janeiro, a. 1, n. 2, jul.-dez./2012, 1-40. http://civilistica.com/a-responsabilidadepre-contratual-por-ruptura-injustificada-dasnegociacoes/ (Consulta: 17 de noviembre de 2018).

Pais De Vasconcelos, Pedro. 2005. Teoria geral do direito civil. $3^{a}$ Edição. Coimbra: Edições Almedina.

Pereira, Fabio Queiroz. 2017. O resarcimento do dano pré-contratual: interesse negativo e interesse positivo. San Pablo: Almedina.
Piraino, Fabrizio. 2015. Il diritto europeo e la «giustizia contrattuale». En: Europa e diritto privato. № 2, 233-293. Milán: Giuffré Editore.

Piraino, Fabrizio. 2017. La natura contrattuale della responsabilità precontrattuale (ipotesi sull'immunità). En: Contratti. 1. Bimestrale di dottrina, giurisprudenza e pratiche contrattuali, 35-61. Milán: Wolters Kluwer Italia.

Roppo, Vincenzo. 2009. El contrato. Traducción de Eugenia Ariano Deho. Lima: Gaceta Jurídica.

Saavedra Velazco, Renzo E. 2009. La responsabilidad precontractual en debate: Panorama de la doctrina jurídica nacional. En: Responsabilidad Civil Contemporánea, 521-573. Lima: ARA Editores.

Sacco, Rodolfo. 1951. Culpa in contrahendo e culpa aquilia; culpa in eligendo e apparenza. En: Rivista del diritto commerciale e del diritto generale delle obbligazione. Anno XLIX. Parte Seconda, 82-91. Milán: Casa Editrice Dottor Francesco Vallardi.

Sacco, Rodolfo y DE NOVA, Giorgio. 2004. I/ contratto. En: Trattato di Diritto Civile. Dirigido por Rodolfo Sacco. Tomo Secondo. Terza edizione. Turín: Utet.

Sacco, Rodolfo. Il fatto, I'atto, Il negozio. 2005. Con la colaboración de Paola CISIANO. En: Trattato di diritto civile. Dirigido por Rodolfo Sacco. Turín: Utet Giuridica.

Salgado Ramírez, Catalina. 2012. Consideraciones históricas acerca de la responsabilidad precontractual antes de Rudolf von Jhering. Aproximación doctrinal. En: Revista de Derecho Privado, número 22 (enero - junio), 277-298. Bogotá: Universidad Externado de Colombia.

Thiene, Arianna. 2009. Inadempimento alle obbligazioni senza prestazione. En: AA.VV. Trattato della responsabilità contrattuale. Inadempimento e rimedi. Dirigido por Giovanna Visintini. Volume Primo. Padua: Cedam.

Turco, Claudio. 2011. Lezioni di diritto privato. Milán: Giuffrè Editore.

Varanese, Giovanni. 2018. Sonderverbindung e responsabilità precontrattuale da contatto sociale. En: Rivista di Diritto Civile 1 (gennaio - febbraio), 116-143. Padua: Cedam.

Zaccaria, Alessio. 2013. Der Aufhaltsame Aufstieg Des Sozialen kontakts (La resistible ascesa del «contatto sociale»). En: Rivista di Diritto Civile 1 (gennaio - febbraio), 77-108. Padua: Cedam. 